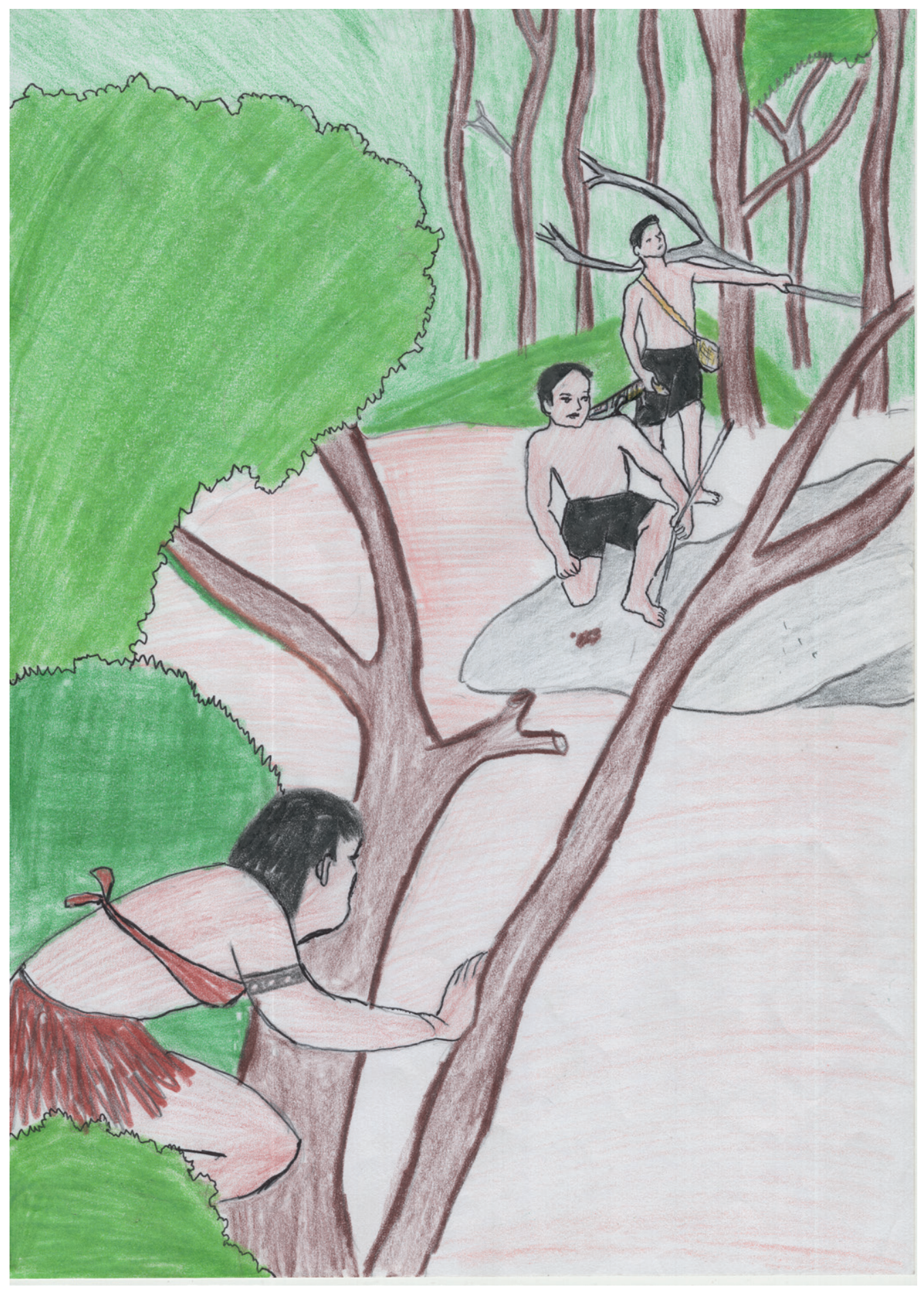




\section{Yatkha Thoxankya Hle de Se Teeke}

Agenor Ferreira de Sá

Ya ho khiaka foente. Nema txidjo khlaka lwa dehe, ooya nendwa fulikha ke. Fuli nendwankya ke ooya khlaka. Nema Ooya etxtxo yatkha thoxankya hle do ooya teeke. Nema hle de ta sa tsoman, txidjo nendwa tha esoka hle de. Netxante ya futxi khiaka de ekhla ehesa, ekka, yeeisese hana khiaka. Ethuya yeetso khiaka de ta kodeke ya sehate. Ya ehesa satona iseka hle de yeehate Nema hle kaske yooka hle de ya txfonte. Nema se khdi, se ke, yawka hle de ya tsfonte tafiawa sato futxiti, xoa, fekhia, khdelaya, walka sato. Nema ya setxtxo yate txlutxlunkya hle de que é a kaypora, ta ya txlutxlunkya hle de. Nema yatkha thoxa watika hle de. Yatkha thoxaman hle yoose ya ekhdedeka hle. Nema ya atxwa neka hle de sedayawa fowa fthone khantese setxtxo edofean. Naati ta oosea hate, khahnen. Nema lwa sedaya lwa dooka hle de? Yaoosea exia khankya hle de. Nema hle de ya kakka noka hle de. Netxante ya toona seekhlema hle yaldjo khlaka hle de kaske. Ta ya te walkankya hle de ya akhay fdate ya holha de ooke. Se teeke ya khtoway yatkha thoxawa watika. Ufnana, ufa; ufnana, ufa; ufnana, ufa; ufnana. Nema ya lewneka hle de.

- Iio. Ya tihaaxi, wey.

- Naati ithlo sato?

- Ithlo sato lewneka, wey, tkoda.

- Tokefle, wey?

- Ta ithlo lwa tkha thoxankya.

Awa se teeke ke toona elkanse. Nema hle de ya sa lhawa tkha thoxanse. Netxante. May neho yasa futxkya hle de. Fthea khethama yawka hle de ya aldeya ke. Ya tilhawa ke ya txman hle ya eldjo khla lay hle. Nekdey xoa, fekhia, fekhya, khdelmalka, que é o sardão. Peteka fthonewa lwa doa khiaka. Ya khodjo khia thloa tkawa. Se não, baduki fthonewa, makhay fthoa ya tafia futxite. Yatlife kaka khiaka de etxfonte. Nema setxfonse khla khiaka de se ke. Netxante ya keha khiaka de txtxaya dey. Yakhodjo dwa. Ya feetonse dwa. Sekefe etxkya etxhaman, ya ho khiaka fonte ftheasa. Ya ho khiaka yalkinte, nekdey ya ho khiaka ya elkinte, nekdey ya txidjo futxi khiaka. 


\title{
A Coisa que Já Atordoava a Gente Dentro do Mato
}

\author{
Agenor Ferreira de Sá
}

A gente estava pescando e tinha muitos peixes e muita água no rio. No rio tinha muita água. Aí a Mãe D’Água atordoava a gente dentro da água. Quando ela se lavava na água, soltava muito peixe e a gente aproveitava e pegava muito: grande, pequeno... Aí nós escolhíamos. Os pequenos, nós soltávamos, porque não dava para a gente comer. Nesse tempo, preparava os grandes para a gente comer. Aí novamente íamos caçar; e nós já íamos caçar por dentro do mato, pegar preazinhos, teiú, camaleão, sardão, mangas. Aí nós éramos atrapalhados pela Caipora. Ela atrapalhava a gente nessa época. Todos nós ficávamos atordoados, sem destino. Quando a gente ficava atordoado, não sabia por onde ir. Então a gente fazia remédio com fumo e colava na pedra para a Caipora fumar. Como é que ela fuma? Apesar que não tinha fumo, mas colocávamos um pouquinho. Aí íamos ficando bom. De repente, quando a gente conseguia algo, a gente tinha muita coisa para comer na aldeia.

Outra vez até a gente brincava, porque a gente andava aqui no mato procurando o que comer, mesmo atordoados nos matos por aqui, lá, por aqui, lá, por aqui, lá, por aqui. E nós ficávamos em silêncio. Aí dissemos:

- Vamos voltar!

- Não, ainda vamos andar. Ainda não é hora de ir.

- E os cachorros?

- Rapaz, os cachorros estão calados.

- Por que, rapaz?

- Bem, os cachorros estão atordoados também.

Também dentro desse mato tem coisa ruim. Aí a gente ficou com a cabeça confusa de repente, mas pelo menos pegamos alguma coisa. No começo da noite, nós já tínhamos chegado na aldeia. Quando nós chegávamos com muitas coisas de novo: teiú, cambambá, camaleão, sardão.

Até uma peteca nós não tínhamos. O nosso trabalho era com faca pequena, não com um bodoque, com uma flecha para pegar preá. Os nossos cachorros eram bons para caçar e tinha muita caça no mato. Assim, a gente comia todo dia. Não tínhamos trabalho. A gente não tinha trabalho mesmo. Quando chegávamos da roça, a gente ia pescar à noite. Toda vez que a gente tomava banho, pegava peixe. 


\section{The thing that stunned us in the bush}

Agenor Ferreira de Sá

We were fishing; there were lots of fish and plenty of water in the river. The river had plenty of water. Then the Mother Water stunned us into the water. When she was bathing in the water, she loosened a lot of fish and we took advantage and collected them all: big fish, small fish... Then we chose the best ones. We let the small ones go, because we couldn't eat them. At that time, we just prepared the big ones for us to eat. Then we would go again hunt; we went inside the bush to get little Brazilian guinea pigs, tupinambis, chameleons, eyed lizards. Then we were hampered by the Caipora. It hindered us at that time. We all got stunned, walking aimlessly. When we got stunned, we didn't know where to go. So we had to trick the Caipora, by sticking some tobacco into a stone for it to smoke. How does the Caipora smoke? We didn't have a lot of tobacco at that time, so we put just a small amount into the stone and waited. When we finally could get something, we would have plenty to eat in the village.

We even used to play sometimes. We walked here in the bush, looking for something to eat, even stunned in the woods, around here and there, here and there, here and there, here. And we we were very silent. Then we said:

- Let's go back!

- No, we'll still walk. It is not yet time to go.

- What about the dogs?

- The dogs are silent.

- Why?

- Well, the dogs are stunned too.

Also within this bush there are stranger things. Then we suddenly got very confused, but at least we caught something. Early in the evening, we had already arrived in the village. We came back with many things again: tupinambis, cambambá, chameleon, eyed lizards.

At that time, we didn't have a shuttlecock. We did everything with a small knife, not with a slingshot. We used an arrow to catch cavy. Our dogs were very good hunters and there were lots of things to hunt in the bush. So we ate all day long. We had no work. There was nothing to do anyways. When we got back home from the crops, we went fishing at night. Every time we bathed in the river, we caught fish. 